\title{
CONCEPT OF TALENT MANAGEMENT IN ENTERPRISES OF SLOVAKIA: FACTORS INFLUENCING STRENGTHS AND WEAKNESSES
}

\author{
Radovan SAVOV; Pavol SKOČDOPOLE \\ Slovak University of Agriculture in Nitra, Slovakia
}

\begin{abstract}
Purpose: As a result of the dynamic environment and changes the concept of talent management has become very important topic in business organizations today. Company with talent management should meet better economic results. Talent management in business environment integrates strategy of the company, HR strategy, identification and recruitment, assessment, development, and retaining talents into complex process. Main objective of this research is to explore the current state of the concept of talent management realized in all phases of talent management in companies operating in Slovakia. According to the results main strengths and weaknesses are identified in the process of talent management.

Design/methodology/approach: Paper is focused on the factors of talent management process such a foreign capital, size of the company, economic situation, ownership, and existence of the HR department. A scaled questionnaire used in previous researches was used as a tool for data collection in 381 companies operating in Slovakia. Questionnaire reliability was verified by Cronbach's alpha and reached the level 0.799 . To verify the existence of statistically significant differences between individual groups of respondents the Kruskal-Wallis test and Mann-Whitney U test were used.

Findings: We found that foreign capital, economic results, and the existence of HR department are very significant factors influencing the level of talent management process in enterprises. Identification of strengths and weaknesses in talent management process were used for suggestions to meet higher level of the processes in management of searched companies.

Research limitations: Research should be extended to more companies to meet the requirements of representative sample. Results should be compared with other similar researches in other countries worldwide.

Practical implications: Each company can use self-evaluation of talent management according to the issues used in questionnaire. Main strengths should be used as a basic stone for personal strategy in companies. Enterprises should avoid mistakes of several companies that lead to weaknesses in the organizations because they have negative impact on economic results and development.
\end{abstract}

Key words: talent, management, process, strength, weakness

\section{Introduction}

Zero waste management can also be used in human resource management. The more talented a company has, the better results can be achieved in the field of zero waste management. Businesses are interested in people bringing new blood in the form of innovative original ideas. People who perform well while trying to move

https://doi.org/10.11118/978-80-7509-820-7-0229

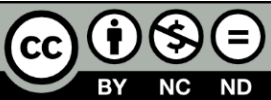


forward, develop themselves, but also the business. Employees who significantly influence the direction of the company and determine its success. They're the people we call talent. If we have people like that on the team, there is a presumption that we will outperform our rivals in the market and achieve satisfactory economic results.

It is therefore a necessity for any company to be able to manage talent. A good guide seems to be a system of talent management, which must be integrated into the company. It is a process that begins with a strategy, where the top management of the company clearly declares that employees are the most important source of the company and a strategic element on which to build the future long-term success of the company. The human resources strategy, with an emphasis on talent support and its consistency with business and business strategy, is the cornerstone on which an integrated talent management process can be built, starting with the identification and acquisition of talent, continuing the evaluation and development of talented individuals, and ending with the maintenance of these talents in the organization.

The main objective of this contribution is to identify factors that influence the management of talent in enterprises. This research is specific because no research is focused on such important factors of development in the area of talent management in companies operating in Slovakia. Main added value is concentrated on identification of strengths and weaknesses of talent management process in companies.

\section{Literature review}

Paper is focused on talented persons who can bring added value. Therefore, we use the word talent for key persons with above normal skills in any area (Silzer and Dower, 2010). Talent management as a key process is defined as a systematic and dynamic process of talent identification, development and retention (Egerová et al. 2015). Raising awareness of talent management and the need for talent in businesses is linked to a number of changes that have taken place in the field of human resources. Tansley (2011). Talent management must first be the philosophy of the top management of the company, otherwise it has no chance of success. The implementation of talent management results from the dynamic development of all business parameters, thus also changing the view of human resources, which has become a strategic issue that helps businesses create a competitive advantage.

Talent management appears to be a critical element that enables organizations to achieve a competitive advantage (Holbeche, 2009). At present, talented people present a competitive advantage, and therefore businesses need such people who can make huge changes. These people are scarce and maintaining them is much more challenging than in the past because they demand ever greater appreciation. They are mobile and have no problem finding and finding an application with better conditions (Bersin, 2013). Craig (2016) consider the greatest contribution of talent management to acquiring a key differentiator that will help distinguish the business from the competition in the current knowledge-based economy. BethkeLangenegger, Mahler and Staffelbach (2011) showed in their study that companies focusing on the talent management has a statistically significant positive impact on 
human resources in the company. People are well motivated, more satisfied with job, and trust in leaders. Talents can improve systematic recruiting system and increase employer branding as well (Froese, 2020). Nevertheless, HRM brings with it various smacks. The main problems related with talent management system are linked to inefficient career planning, promotion and motivation of talented employees (Daciulyte and Stankevich, 2015).

\section{Methodology}

The research was carried out on a sample of 381 companies carrying out their business activities in Slovakia. The research sample was randomly determined. A questionnaire was used to obtain the data. The introductory part of the questionnaire consisted of classification items, where respondents reported the size of the enterprise, ownership, participation of foreign capital, economic results of the enterprise and the existence of a human resources unit. The main part consisted of 41 items (table 1), which were divided into five phases of talent management strategic concept of human resources with regard to talent management, identification and acquisition of talent, talent assessment, talent development and talent retention. The individual items of the questionnaire were created as notification sentences in which individual respondents expressed the degree of consent. To do this, Likert scale of 1-5 was designed, where a value of 5 expressed absolute consent, a value of 3 neutral attitude and a value of 1 absolute disapproval. In order to identify statistically significant differences in respondents' responses in individual items according to sorting criteria (size of enterprise, ownership, participation of foreign capital, economic performance of the enterprise, existence of a human resources unit) parametric testing was also performed by the KruskalWallis test and the Mann-Whitney test, respectively. All statistical tests were carried out at an alpha $=0.05$ significance level, through the SPSS statistical programme.

\section{Table 1. Items in the questionnaire}

Strategy
Talent management is essential (I1).
Talent management is an important part of our company's mission (I2).
Top management worked out a joint attitude towards talent management (I3).
We have a clearly defined human resources management strategy (I4).
We have a clearly defined talent management strategy (I5).
Talent management strategy is connected with strategic goals of our organization (I6).
We are currently modifying the list of key talents indispensable in our company (I7).
We search for talent in every single person that has just been employed (I8).
Formulated talent management strategy is not difficult to realize in our company (I9).
Identification
All positions in our company have been divided into key and peripheral positions (I10).
Our workers' competences are adapted to their position requirements (I11).
We are currently identifying talents among all the workers employed in our company (I12).
We are currently identifying positions we need to recruit candidates for from the external environment (I13).
We apply a plan of attracting talents from the external environment (I14).
Our recruitment system makes it possible to acquire people of the highest development potential (I15).
We know quite a lot about talents our employees have (I16).
Talented people are willing to get employed by our company (I17).
We know what talents we are going to need in the future (I18).




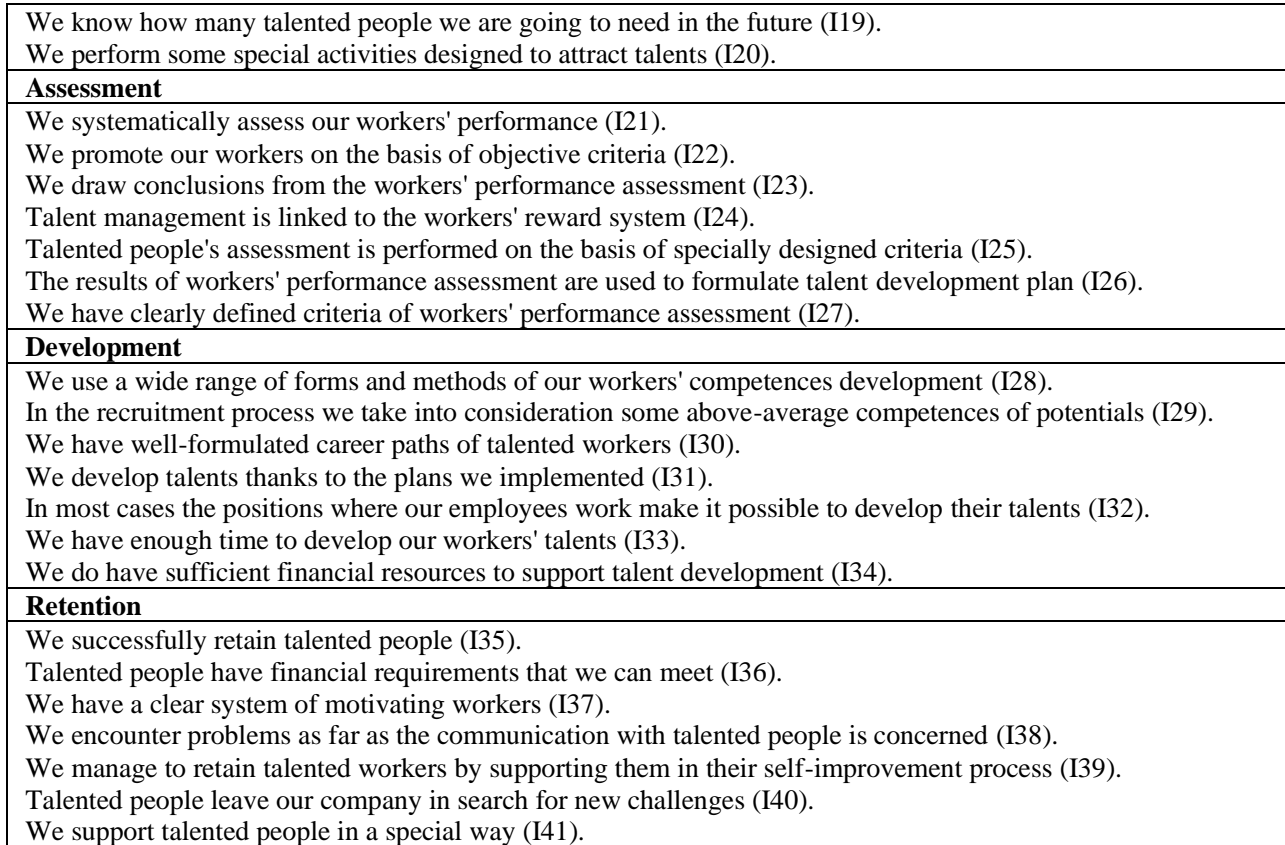

Source: own results

\section{Results and discussion}

The aim of the research was to uncover factors that influence the management of talent in enterprises and identify the strengths and weaknesses of talent management in companies operating in Slovakia. Research carried out on a sample of companies operating in Slovakia showed a number of differences in talent management between companies in terms of several criteria. The first factor examined was the size of the companies. This factor identified 17 statistically significant differences between SMEs and large enterprises. The items in which differences in the notion of talent management have been recorded are shown in Table 2.

Table 2. Statistically significant differences according to size of the company

\begin{tabular}{|c|c|c|c|c|c|c|c|c|c|}
\hline SIZE & 14 & 15 & 17 & 113 & 114 & 118 & 119 & 120 & 121 \\
\hline Chi-Square & 26.923 & 16.568 & 11.063 & 9.584 & 11.748 & 8.079 & 7.676 & 12.431 & 24.921 \\
\hline \multirow[t]{2}{*}{$p$ value } & 0.000 & 0.000 & 0.004 & 0.008 & 0.003 & 0.018 & 0.022 & 0.002 & 0.000 \\
\hline & 125 & 126 & 127 & 128 & 129 & 131 & 134 & 140 & \\
\hline Chi-Square & 7.367 & 7.988 & 8.391 & 18.729 & 11.432 & 11.105 & 7.396 & 7.967 & \\
\hline$p$ value & 0.025 & 0.018 & 0.015 & 0.000 & 0.003 & 0.004 & 0.025 & 0.019 & \\
\hline
\end{tabular}

Source: own results 
The second factor examined is the ownership of the business. In terms of this criterion, we found 13 statistically significant differences between private and stateowned enterprises. The identified differences are given in Table 3.

Table 3. Statistically significant differences according to ownership of the company

\begin{tabular}{|c|c|c|c|c|c|c|c|}
\hline OWNERSHIP & $\mathbf{I 1 0}$ & 116 & 117 & 121 & 125 & 126 & 129 \\
\hline $\begin{array}{l}\text { Mann-Whitney } \\
\text { U }\end{array}$ & 4431.50 & 3898.50 & 3618.00 & 4363.00 & 3696.00 & 3922.00 & 3735.00 \\
\hline \multirow[t]{2}{*}{ p value } & 0.043 & 0.015 & 0.003 & 0.025 & 0.034 & 0.009 & 0.010 \\
\hline & 135 & 137 & 138 & 139 & 140 & 141 & \\
\hline $\begin{array}{l}\text { Mann-Whitney } \\
\text { U }\end{array}$ & 3831.00 & 4225.00 & 3918.00 & 3694.50 & 3866.50 & 3558.00 & \\
\hline$p$ value & 0.014 & 0.042 & 0.030 & 0.012 & 0.011 & 0.022 & \\
\hline
\end{tabular}

Source: own results

Another factor examined was the representation of foreign capital in the company. According to this criterion, 26 statistically significant differences were identified between enterprises with purely Slovak capital and enterprises where foreign capital is represented. The identified differences are given in Table 4.

Table 4. Statistically significant differences according to capital allocated in the company

\begin{tabular}{|c|c|c|c|c|c|c|c|c|c|}
\hline CAPITAL & 13 & 14 & 15 & 16 & 17 & 110 & 113 & 114 & 115 \\
\hline Mann-Whitney U & 13063.0 & 11284.0 & 11280.0 & 11713.5 & 11080.5 & 14682.5 & 13688.5 & 11581.0 & 14400.0 \\
\hline \multirow[t]{2}{*}{$p$ value } & 0.014 & 0.000 & 0.000 & 0.000 & 0.000 & 0.040 & 0.044 & 0.001 & 0.036 \\
\hline & 117 & 119 & 120 & 121 & 122 & 124 & 125 & 126 & 127 \\
\hline Mann-Whitney U & 13712.5 & 12656.5 & 10631.5 & 12366.5 & 14228.0 & 12233.0 & 11798.5 & 12454.0 & 12400.0 \\
\hline \multirow[t]{2}{*}{ p value } & 0.009 & 0.012 & 0.000 & 0.000 & 0.047 & 0.001 & 0.002 & 0.000 & 0.001 \\
\hline & 128 & 130 & 131 & 133 & 134 & 137 & 139 & 141 & \\
\hline Mann-Whitney U & 10395.0 & 11287.5 & 11209.5 & 13100.0 & 13092.5 & 13990.0 & 13356.5 & 11832.0 & \\
\hline$p$ value & 0.000 & 0.000 & 0.000 & 0.007 & 0.007 & 0.017 & 0.032 & 0.005 & \\
\hline
\end{tabular}

Source: own results

Next factor, which was the economic situation of the company, recorded 24 statistically significant differences in respondents' responses. The identified differences are given in Table 5. 
Table 5. Statistically significant differences according to economic situation of the company

\begin{tabular}{|c|c|c|c|c|c|c|c|c|}
\hline ECON.SIT. & I1 & 12 & 13 & 14 & 15 & 16 & 18 & 19 \\
\hline Chi-Square & 18.162 & 13.955 & 24.477 & 14.479 & 13.326 & 11.944 & 10.234 & 6.144 \\
\hline \multirow[t]{2}{*}{$p$ value } & 0.000 & 0.001 & 0.000 & 0.001 & 0.001 & 0.003 & 0.006 & 0.046 \\
\hline & I15 & I16 & I17 & 121 & 122 & 124 & 126 & 128 \\
\hline Chi-Square & 13.714 & 10.496 & 11.582 & 8.351 & 9.492 & 14.041 & 19.055 & 18.407 \\
\hline \multirow[t]{2}{*}{$p$ value } & 0.001 & 0.005 & 0.003 & 0.015 & 0.009 & 0.001 & 0.000 & 0.000 \\
\hline & 130 & 131 & 133 & 134 & 135 & 136 & 137 & 139 \\
\hline Chi-Square & 15.230 & 14.279 & 15.606 & 32.605 & 24.636 & 24.629 & 7.964 & 23.221 \\
\hline p value & 0.000 & 0.001 & 0.000 & 0.000 & 0.000 & 0.000 & 0.019 & 0.000 \\
\hline
\end{tabular}

Source: own results

The last factor examined was the existence of a human resources department. Within this factor, 25 statistically significant differences in responses were identified between companies which have an HR department and companies which do not have such separation. The identified differences are given in Table 6 .

Table 6. Statistically significant differences according to existence of HR department in the company

\begin{tabular}{|c|c|c|c|c|c|c|c|}
\hline HR DEPT. & 13 & 14 & 15 & 16 & 17 & $\mathbf{I 1 0}$ & $\mathbf{I 1 1}$ \\
\hline Mann-Whitney U & 11987.0 & 9724.0 & 11750.0 & 12611.5 & 10763.5 & 13012.0 & 13728.0 \\
\hline \multirow[t]{2}{*}{$p$ value } & 0.001 & 0.000 & 0.000 & 0.002 & 0.000 & 0.002 & 0.009 \\
\hline & 112 & I13 & I14 & I15 & I18 & 119 & 120 \\
\hline Mann-Whitney U & 11294.5 & 12186.0 & 10455.5 & 12292.5 & 11949.0 & 11187.5 & 10499.0 \\
\hline \multirow[t]{2}{*}{$p$ value } & 0.000 & .001 & 0.000 & 0.000 & 0.000 & 0.000 & 0.000 \\
\hline & 121 & 122 & 124 & 125 & 126 & 127 & 128 \\
\hline Mann-Whitney U & 11572.5 & 13129.0 & 12233.0 & 11058.5 & 11827.0 & 11639.5 & 9253.5 \\
\hline \multirow[t]{2}{*}{$p$ value } & 0.000 & 0.009 & 0.003 & 0.000 & 0.000 & 0.000 & 00.000 \\
\hline & 130 & 131 & 140 & 141 & & & \\
\hline Mann-Whitney U & 10543.5 & 10798.0 & 13072.0 & 12007.5 & & & \\
\hline
\end{tabular}




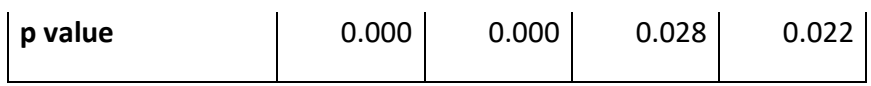

Source: own results

As should be seen, the most important factor influencing talent management are the economic results of the company. These affect every single part of the talent management process. Most strikingly, the first. which is aimed at linking the human resources strategy to the company's strategy. Businesses with improved economic results show a greater focus on human resources as a strategic element of the company's growth. At the same time, they are able to invest more money in the development of talented individuals. as undertakings with impaired economic results. which documents a number of differences in the talent development phase compared to other enterprises.

The second most important factor influencing the talent management process is the existence of a human resources unit in the organizational structure. This plays an important role, in particular, in identification. talent acquisition and evaluation. As can be seen from the table. it is at these stages that the most differences can be seen compared to businesses. which do not have such organisational units. The HR department carries out many activities. to gain talent. identify them while drawing up the basis for talent assessment. for which undertakings without such a unit do not have sufficient human capacities. to develop an appropriate evaluation system. Foreign capital and the size of the business are also factors. that affect the process of talent management at all its stages. Ownership of the business appears to be the least influential factor. No differences between SOEs and private enterprises were identified at the strategy and identification phases. However, this factor has been shown significantly at the stage of retaining talent. At this stage, only seven items showed a difference. from which it can be judged. that private enterprises are significantly more successful. than state.

\section{Conclusion}

Talented individuals can greatly help to improve zero waste management. The aim of the research was to identify strengths and weaknesses in the process of talent management in companies in Slovakia. The results show. that it is best for businesses to do so, in particular in terms of the strategic concept of human resources and the identification of talent. on the contrary. they are worse off in terms of the next stages of talent management than evaluation. development and retention of talent. It is here that we can see opportunities to further improve the talent management in these companies. It is improvements in weaknesses that could lead to an overall improvement in talent management in these enterprises.

The most serious strengths in the talent management process can be considered:

- talent management is seen strategically as very important,

- talent management is an important part of the business mission,

- is a defined human resources management strategy,

- jobs are divided into key and other, 
- the job competences of employees are adapted to their job position,

- staff performance is systematically assessed and evaluations draw conclusions suitable for planning talent development,

- the staff reward system is based on objective criteria,

- the selection process takes into account their above-average skills,

- communication with talented individuals is at a high level.

On the contrary. weaknesses are in particular the following:

- the talent management strategy is considered difficult to implement in enterprises,

- businesses do not carry out special activities aimed at attracting talent,

- the career development planning system is not well redesigned,

- predetermined plans are not used to develop talents,

- there is not enough financial resources in enterprises to develop talent,

- fails to meet the financial requirements of talented employees,

- specific procedures are not used to retain talent and therefore, due to the

existence of other challenges.

HR management focusing on talents is on higher level in large companies what was confirmed by other authors in previous research (Boštjančič and Slana, 2018; Valverde, et al. 2013). They summarized that talent management in SME is more unplanned, unsystematic, and intuitive, compared to large companies. What is very interesting result from our results, retention is more successful in small companies because we did not find similar results in the previous literature. Other factors such an ownership, foreign capital, and economic situation are in line with the results of previous studies (Valverde, 2013; Krishnan and Scullion, 2017; Ready et al., 2010). In these cases, private companies, companies with foreign capital, and companies with better economic performance has higher level of talent management integrated into managerial system. We added existence of HR department as another factor influencing in our research what can be understand as novelty into this kind of research because companies with HR department has specialists who can carry out on activities connected with talent management and therefore it is on higher level compared to companies where HR department is not implemented.

\section{References}

1. Bersin, J. (2013). Employee retention now a big issue: Why the tide has turned. Bersin by Deloitte, 16, 1-4.

2. Bethke-Langenegger, P., Mahler, P., \& Staffelbach, B. (2011). Effectiveness of talent management strategies. European Journal of International Management, 5(5), 524-539.

3. Boštjančič, E., \& Slana, Z. (2018). The role of talent management comparing medium-sized and large companies-major challenges in attracting and retaining talented employees. Frontiers in psychology, 9, 1750. doi.org/10.3389/fpsyg.2018.01750

4. Craig, D. (2016). Transforming culture through personal and career empowerment. Industrial and Commercial Training. http://dx.doi.org/10.1108/ICT-08-2015-0054

5. Daciulyte, R., \& Stankevich, K. (2015). A systemic approach to talent management: managers' perceptions versus employees'. International Journal of Business and Emerging Markets, 7(3), 223-236. DOI: 10.1504/IJBEM.2015.070337 
6. Egerová, D., Lančarič, D., Eger, L., \& Savov, R. (2015). Perspectives of talent management: Evidence from Czech and Slovak business organisations. Economics and Management. DOI: 10.15240/tul/001/2015-4-008

7. Froese, F. J., Shen, J., Sekiguchi, T., \& Davies, S. (2020). Liability of Asianness? Global talent management challenges of Chinese, Japanese, and Korean multinationals. Human Resource Management Review, 30(4), 100776. https://doi.org/10.1016/j.hrmr.2020.100776

8. Holbeche, L. (2009). Aligning human resources and business strategy. Routledge.

9. Krishnan, T., and Scullion, H. (2017). Talent management and dynamic view of talent in small and medium enterprises. Hum. Res. Manag. Rev. 27, 431-441. doi: 10.1016/j.hrmr.2016.10.003

10. Ready, D. A., Conger, J. A., \& Linda, A. Hill. 2010.“Are You a High Potential?”. Harvard business review, 1-7

11. Silzer, R., \& Dowell, B. E. (2010). Strategic talent management matters. Strategy-driven talent management: A leadership imperative, 3-72.

12. Tansley, C. (2011). What do we mean by the term "talent" in talent management?. Industrial and commercial training. http://dx.doi.org/10.1108/00197851111145853

13. Valverde, M., Scullion, H., and Ryan, G. (2013). Talent management in Spanish mediumsized organisations. Int. J. Hum. Res. Manag. 24, 1832-1852. doi: $10.1080 / 09585192.2013 .777545$ 